\title{
Allen Oakley's Contribution to History of Political Economy: Capitalism, Agency-Structure and Realism
}

\author{
Phillip Anthony O’Hara*
}

\begin{abstract}
Allen Oakley has been a consistent and innovative contributor to the history of political economy for thirty years. His contributions span a wide spectrum, from the classical economics of Adam Smith and John Stuart Mill, through to the dynamics of capitalism associated with the work of Karl Marx and Joseph Schumpeter, and more latterly the Austrian school and beyond. His work on Marx links to the evolution and conceptual development of his political economy of capitalism, while for Schumpeter he took a critically sympathetic view of his theory of development and cycles. He also worked on issues of methodology, including Adolf Lowe's structural and instrumental analysis, and Karl Popper's situational perspective. More recently, he has scrutinised the contradictions of Austrian thought associated with subjectivism versus market order. He sought to resolve the question of agency-structure through reconstructing political economy along the lines of a critically realistic view of hermeneutic cross-causation between individuals and society.
\end{abstract}

\section{$1 \quad$ Introduction}

The purpose of this paper is to analyse the contribution of Allen Oakley to the history of political economy. Specifically, three things stand out. First, Oakley contributed to an understanding of the inner dynamics of capitalism. Using the work of Karl Marx and Joseph Schumpeter, he developed a critical appreciation of the evolution of their political economies of capitalism.

Second, Oakley advanced an understanding of the relationship between structure and agency. How can individuals engage in action while systemic forces influence their decisions, both limiting and assisting their objectives? Special reference in this regard is given to the Austrian School of political economy, with Oakley endeavouring both to appreciate and critically assess-as well as to improve and transcend-its understanding of this central problem.

Third, interspersed with the first two themes, Oakley was very interested in questions of methodology, and how best to comprehend political economy processes. He focused on a number of individuals, primarily Adolf Lowe, Karl Popper and Alfred Schutz. Oakley advanced a realist method of economic discourse and sought an understanding of real economies through historical time.

A biographical section is included to lay the groundwork for understanding Oakley's origins and why he studied political economy in the first instance. It also summarises his contributions to institution-building in political economy. It is to these biographical questions that we now turn.

\section{Biographical Issues}

Allen Charles Oakley was born in Adelaide on 22 July $1943 .{ }^{1}$ Oakley's ancestors were South Australian 'first fleeters' (Oakley 2006). He is a descendant of Josiah 
Oakley (1795-1876), who arrived from England with his wife and eight children on the first free migrant ship, HMS Buffalo, in 1836 (under the Wakefield Scheme). During the early years of Allen's childhood, his father was a printing tradesman and his mother a retail shop worker. Both later managed and owned hotels in South Australia for most of his school years. This was, perhaps, some throwback to the fact that in 1837, Josiah Oakley bought land in Gilles Street, Adelaide and founded the first hotel in Adelaide, initially in a tent. Later it became the Oakley Arms Hotel.

The hotel business meant many moves between towns and cities throughout South Australia and a much disrupted school life. Allen left school in 1960 after five years of high school and completing matriculation. His intention was to enrol in science at Adelaide University. Studying law would have been preferred, but he did not have the required matriculation Latin to enrol. As things turned out, he decided not to go to university just then as he wanted to be independent and travel. As Allen (2006) says, 'this phase of my life is best left blank as it lacks significance or lasting achievement'.

However, he soon had the opportunity to begin tertiary studies while in Western Australia in the early 1960s. He studied for the Teaching Diploma at Graylands Teachers College (later absorbed into Edith Cowan University), and graduated in 1965. Some 'inauspicious years as a teacher' followed. Meanwhile, he studied part-time at the University of Western Australia. He began with first-year physics, which he passed. Subsequent vocational thoughts beyond teaching led him to accounting and eventually to economics. He took both accounting and economics at first-year level at University of Western Australia and passed.

In 1969, he decided to return to South Australia and took up a State Government Teaching Scholarship to attend the University of Adelaide. Full-time Bachelor of Economics studies followed, with some academic successes. He did his honours year and achieved a first, graduating in 1972. His honours year brought him into close contact with Geoff Harcourt, who was to become the main influence on his academic work. It was with his imprimatur that he chose a history of thought topic for an honours thesis. 'At that time', as he said, 'such a choice was not yet the kiss of academic death’ (Oakley 2006, p. 3).

To be allowed this choice was a 'blessing', Oakley (2006) noted, as he had already 'formed some profound misgivings about, and had little empathy with, the state of the contemporary orthodox economics presented in the classroom'. It was under Harcourt's tutelage that his interest in heterodox economic ideas began to form. ${ }^{2}$ The title of his Honours Thesis was The Theory of the Rate of Profits in English Economic Thought (Oakley 1972), supervised by Harcourt. He sought to compare and contrast the work of David Ricardo with the work of Alfred Marshall on the rate of profits. It was, however, a project that posed more questions for Oakley than it answered. As he says, 'my First that year suggests that the Examiners warmed to my efforts more than I did!'.

The South Australian Department of Education authorities were impressed with his academic record to the extent that he was appointed Lecturer in Economics at Adelaide Teachers College, soon to be transmogrified into Adelaide College of Advanced Education in 1973, and later the University of South Australia. His appointment allowed him to enrol as a PhD student at the University of Adelaide in 1973, with the additional good fortune of having Geoff Harcourt as his supervisor. His topic was Marx's theory of surplus value. Again, 'a choice that was then not as suicidal for an academic career in economics as it would be today'. 
From 1973 until 1980, he 'spent every spare hour on the mutually interactive processes of reading most of what Marx had written that had found its way into print and shaping my critical responses into a thesis'. He went on to say that 'there were moments, long periods even, of despair as I waded through hundreds of pages of turgid prose. This was an endeavour made worse, I was later to realize, by the highly variable quality and accuracy of the translations (my German at the time was just not up to the originals).' The $\mathrm{PhD}$ was awarded in 1980, under the title of The Evolution and Critico-Analytical Significance of Karl Marx's Theory of Surplus Value Prior to Capital (Oakley 1980).

Why should he have chosen Marx for his PhD? The choice originated 'in a burgeoning fascination with the history of political economy that accompanied my degree studies and my subsequent teaching experience. The choice of Marx as my focus was inspired by a reading of, and a burning desire to emulate, what I found in Bob Heilbroner's The Worldly Philosophers' (1953). To this day, Allen 'believe[s] there is no more pleasurable and informative way to be exposed to the wonders of HET than to read Bob's outstanding prose. In particular, he brought Marx to life for me, and posed enough questions about the man and his work to dominate my intellectual activities for the next several years' (Oakley 2006).

It was after some early publication success while still working on his thesis that he decided to attempt to find a university position. This, he hoped, would give him more time for research by reducing the time spent teaching. At the time, few suitable opportunities for such a mature-aged academic novice were available, even though he was prepared to move to another state. As Oakley said, 'Newcastle beckoned with an advert for a Lecturer prepared to start at the bottom of the salary range and with no particular specialization demanded. I wrote to Clem Tisdell, then the Head of Department, about the position and received a reply that encouraged me to apply. This I did and the first result was an interview in Newcastle early in 1977'. Oakley went on to say that:

I was offered the position not quite at the bottom of the salary scale for lecturers and with some study leave credit from my CAE time. Whatever negative misinformation I had been fed about the city of Newcastle itself, this was too much of an opportunity to pass up. And, I remain extremely grateful for Clem's faith in my abilities on the basis of what, by then, was only very slim evidence of academic success or potential. Behind the scenes, the late Barry Gordon may have encouraged my appointment in order to acquire a younger colleague whose dominant interest was in HET. (Oakley 2006, p. 3)

Oakley researched and taught at the University of Newcastle, Department of Economics (now called the 'School of Economics, Politics and Tourism'), between 1977 and 2003. He was promoted to Senior Lecturer in 1983, and Associate Professor in 1990. His main teaching areas were undergraduate and honours history of economic thought, macroeconomics, economic philosophy, as well as second and third year money and financial institutions. He was also a Visiting Professor at various places, such as the Department of Political Economy, University of Toronto (1981); the Faculty of Economics and Politics at Cambridge University (1981); the Institut für Höhere Studien, Vienna (1987-1988); and the Institut für Wirtschaftswissenschafen, University of Vienna (1-3 months of every year during 1994-2003).

While at Newcastle he was a supervisor for a number of honours and masters students as well as three $\mathrm{PhD}$ theses. The $\mathrm{PhD}$ theses he supervised 
included one on Marxist and institutional political economy by Phillip O'Hara (1992), a reconstructed and extended version of which was published as a book (O’Hara 2000); another on Kaleckian investment cycles by Jerry Courvisanos (1994), which also emerged as a book, with additional applications to advanced capitalist economies (Courvisanos 1996); and a third by Bill Mitchell (1999) on the topic of essays on inflation and unemployment. Oakley was also on the editorial board of History of Economics Review (1990-2005); organiser of the fourth History of Economic Thought Society of Australia conference in Newcastle (1987); editor of the Newcastle Economics Department Research Report or Occasional Papers series (1982-87); and a member as well as area correspondent of the International Network for Economic Method (INEM).

\section{The Inner Dynamics of Capitalism: Marx}

Oakley's first major project, and in a sense at the core of his life's work, is to understand capitalism as a system. His $\mathrm{PhD}$ thesis analysed the evolution and development of Marx's work prior to Capital, and this work was published in a number of international journals, such as Economica (Oakley 1976) and History of Political Economy (Oakley 1979), as well as in three books. Three things stand out in this work from the point of view of the dynamic motion of capital. The first is that Oakley emphasised the evolutionary nature of Marx's political economy of capitalism. The second is that he demonstrated how and why Marx focused on the notion of contradiction. The third is that the social reproduction process is seen as the critical element of Marx's perspective on capitalism.

The first of these is the evolutionary process whereby Marx developed his critical analysis of capitalism. Oakley emphasises this more than anyone else, and he was thus able to situate Marx's work in a much more holistic methodological perspective. Most previous analysts of Marx overemphasised or assumed the completed nature of Capital, and many even emphasised the production process devoid of circulation. ${ }^{3}$ Oakley set the stage by telling us that Marx's desired or required political economy of capitalism was quite possibly a whole series of models that included a six-book plan. Whether Marx thought he could have finished this in his lifetime is uncertain, but he probably realised he could not. Nevertheless, such a multi-book plan is possibly required even though others would have to undertake much of the work themselves. The problem was that no political economist studied in detail the possible need for and nature of such a plan before Oakley's work emerged. ${ }^{4}$

The six-book plan, while having slight variations, generally included the following (Marx 1857-58, 1859, 1862-63):
1. Capital
2. Wage Labour
3. Landed Property
4. State
5. International Trade
6. World Market and Crises

According to Oakley, Marx probably realised the likely need to extend the analysis to these six areas, where the method is one of successive approximation from the relatively 'abstract concrete' to the 'real concrete' dynamics of capitalism. According to this plan, political economy thus starts with 1. Capital (production, 
circulation, competition, break-up of surplus), and then capital is detailed in relation to 2. Wage Labour; then capital and wage labour is linked to 3. Landed Property. The three great social classes of capitalism thus constitute the first three books. The final three books, initially, link the first three to 4 . The State; then the first four integrate with 5. International Trade; and finally the first five relate to the more concrete material of 6 . World Market and Crises. Marx believed that only when we get to the sixth book would the system be examined in all its complexity and concreteness. But, even though something like the six-book plan may be required, 'There is ... little bibliographical evidence to go on in assessing Marx's intentions with respect to the status of Capital vis-à-vis the original Six-Book plan' (Oakley 1983a, p. 114). ${ }^{5}$

Aspects of the evolutionary nature of Marx's work are detailed in Oakley's first book, The Making of Marx's Critical Theory (Oakley 1983a), and in the 'invited lecture' on the occasion of the centenary of the birth of Karl Marx, 'What is Capital?', presented at the second History of Economic Thought Society of Australia Conference, University of Sydney (Oakley 1983b) and included in this issue. In these works, he goes into much more detail on this theme, finding, for instance, that Capital is possibly only the beginning of a much more extended analysis of capitalism. As argued also in the Communist Manifesto, Marx sees capitalism as primarily a world system - with forms of uneven developmentwhere crises and reproduction need be scrutinised at the global level. In the Grundrisse, Marx proposed that the core contradictions of capitalist motion display a necessary global dimension; but where this global system adds a further layer of potentially anomalous reproduction. As he said, 'The tendency to create the world market is directly given in the concept of capital itself' since 'A precondition of production based on capital is ... the production of a constantly widening sphere of circulation' (Marx 1857-58, p. 407-8).

Evolutionary analysis is also important in recognising the core role of the Grundrisse within Marx's scientific works. The pre-1857 works of Marx were of a relatively low level of sophistication. The winter months of 1857-58, when Marx worked on the Grundrisse, saw the development of most of the core elements of his political economy of capitalism, usually in a less formal mode of presentation than Capital. These include the notions of production and circulation; labour and labour power; constant and variable capital; variable capital and surplus value; surplus value and profit; productive and unproductive activities; and competition and profit. Furthermore, while the Grundrisse was developmental, it was much wider than Capital in its scope, even if the six-book plan was of ambiguous significance in terms of what Marx set himself to complete. As Oakley said: 'Probably more than most other writings in intellectual history, Marx's Capital should not be read in isolation from its bibliographical and theoretico-evolutionary context' (Oakley 1983a, p. 106).

The first volume of Oakley's two-volume work on Marx's Critique of Political Economy concerns the Grundrisse and the writings that led up to it (Oakley 1984; reprinted in 2003), while the second analyses the Theories of Surplus Value (Oakley 1985; reprinted in 2003). What is remarkable is that these works were not subject to a thorough political economy analysis prior to Oakley's work. This is perhaps understandable in the case of the Grundrisse (Marx 1857-58), given its relative inaccessibility for over a hundred years, and complete translation into English as late as 1973. No such justification, however, exists in the case of Theories of Surplus Value (Marx 1862-63; part of a wider study, Marx 1861-63). In 
these books, Oakley rightly dismisses talk about the gulf between the early and later Marx, especially since the Grundrisse links alienation with the creation of surplus value. Also, Oakley takes a middle point between the divergence-andcontinuity theme, vis-à-vis Marx and the classical political economists; Marx went beyond, but also represents to a degree a continuation of, classical themes.

Secondly, Oakley was one of the first scholars to discuss in some detail the importance of the notion of contradiction. Most analysts uncritically recognise Marx was interested in contradictions, but they generally leave the concept undefined and unresolved. Oakley rectified this problem by examining in some detail the different contexts in which Marx used the notion. Contradictions are seen as internal relations that generate immanent systemic problems to varying degrees through time. They are inextricably linked to capitalism's inner motion, although they have both a temporal and spatial variability, which must be closely analysed in order to comprehend the core problems.

The notion of contradiction is especially notable in Oakley's Economica article, his History of Political Economy essay, and also the closing chapters of volume two of Marx's Critique of Political Economy. The Economica article considered one principal contradiction examined in Marx's critique of political economy, namely, 'the contradiction between the apparent and the actual movement of the system' (Marx 1862-63, II, p. 166). Here Oakley discussed the systemic contradiction between the general movement of capital which generates labour values and surplus value, and the real-world appearances of money prices and profit. They are both analysed by Marx, but they exist at different levels of inquiry, with the former irrevocably underpinning the existence of the latter. Marx thus sought to explain the underlying production of labour values and surplus within the sphere of production, and to link this with the phenomenal forms of money, prices and profit in capitalist markets.

The critical thing for Marx is not only that the two spheres are relatively autonomous yet linked, but also that contradictions operate within both spheres and are integral to the complex workings of capital. The transformation of values into prices and surplus into profit is thus scrutinised in order to clarify the different levels of analysis within which capitalism operates. There are contradictions within the sphere of production, since surplus value depends upon variable capital, yet constant capital tends to grow faster than variable capital. There are also contradictions within the sphere of circulation, since the separation of buying and selling provides the potential for a crisis, while the sphere of circulation may temporarily seek to surmount the limits of production, thus generating excess fictitious capital and prices out of line with fundamental values.

Marx's work, Oakley recognises, is a masterful analysis of the complex workings of capitalism in its various forms and levels. For Marx, the key critique focused on simple-minded views of the political economy of capitalism that ignored these complicated production-circulation contradictions and dynamics. Say's Law, balanced growth and market freedom were thus myths expounded by those who sought an unduly abstract view of capital and thus failed to recognise the thoroughly revolutionary and potentially unstable nature of the system. Marx thus sought to provide a more realistic analysis of capitalism, based on the workings of the trade cycle, monetary crises and speculative excesses. Variously higher and lower rates of accumulation and growth occur in different cycles and epochs. Linking the positives and negatives to accumulation and contradiction, Oakley believed, enabled Marx to provide a foundation for a coherent critical view of capitalist dynamics. 
Thirdly, Oakley realised that Marx's major contributions to political economy are to be found in his critique of the process of social reproduction. Most contemporary Marxists have emphasised the narrow aspects of production, without recognising it was the social view of Marx that gave him an advantage in comprehending the system of capitalism. Marx's critique of capitalism provided seminal insights into the contradiction of individual-social relations. Liberty and freedom exist when capital is deregulated and its power is unconstrained. Yet the social foundations of capital are grounded in exploitation, since the means of production are not controlled by the workers, but instead are owned by private individuals and corporations. Inside the production process, workers are denied power and thereby can have access to no more than a mere wage, while absentee and non-participating owners receive an unearned surplus.

Thus, behind freedom exists exploitation, since labour power receives only a wage, while labour itself produces a value equal to wages plus surplus. In denying labour the ability to control capital, the unearned surplus potentially leads to periodic underconsumption and overproduction. Not only are those who produce different from those who consume out of unproductive remuneration, but unproductive use of the surplus may well be needed to ensure rapid accumulation. However, if the unproductive use of the surplus is too advanced, it may lead to unstable reproduction in the form of low productivity, speculative bubbles and inadequate demand. Coordination of the whole process of reproduction is unplanned, disarticulated and uncertain. This leads to varying degrees of investment and credit instability over time.

Oakley's work on Marx was well received in the journals. The Making of Marx's Critical Theory was reviewed by John Elliott (1987) in History of Political Economy. Elliott found that it 'provides an invaluable analytical guide to this complex, incomplete, evolving literature', while 'it is a valuable guide to a significant, and typically neglected, aspect of Marx scholarship'. Elliott (1986) went on in the American Political Science Review to scrutinise Oakley's twovolume Marx's Critique of Political Economy, concluding that it 'provides a masterful examination of Marx's critique of political economy', and 'is an important, needed and unique contribution' to political economy. These two volumes were also favourably reviewed by Michael Evans (1985a) in The Manchester School. Evans had some reservations about the first volume, especially Oakley's interpretation of whether Marx's method was 'empirical rather than empiricist', and in relation to some similarities between Marx and J. S. Mill on the possibility of crises (Evans 1985a). On the second volume, Evans sings the praises of Oakley's work, since, concerning Theories of Surplus Value, 'it is astonishing that, as Oakley points out, there has been no previous study devoting a sustained effort to the overall analysis of these manuscripts'. He concludes that, 'For this reason alone this second volume is of major importance, in its contribution to the understanding of Marx's intellectual development'. Furthermore, 'Oakley's analyses are clear, cogent and succinct, keeping close to the textual evidence' (Evans 1985b). A testament to the value of these two volumes is that the publisher reprinted them after twenty years, as foundational works in the history of political economy.

\section{$4 \quad$ Innovation and Business Cycles: Schumpeter}

Oakley also examined the dynamics of capitalism through the prism of Joseph Schumpeter's analysis of innovation and the business cycle. Oakley's book, 
Schumpeter's Theory of Capitalist Motion (Oakley 1990) is a masterly scrutiny of the nature of, and problems with, Schumpeter's theory. He commences with a number of chapters outlining Schumpeter's approach to the circular flow, capitalism, motion, development and money and credit. Then he centres on Schumpeter's primary cycle plus the secondary wave. He concludes the book with some constructive criticisms of Schumpeter.

It is important to emphasise that Schumpeter's analysis of innovation and business cycles developed in two main works, the first being The Theory of Economic Development (Schumpeter 1911), and the second Business Cycles: A Theoretical, Historical and Statistical Analysis of the Capitalist Process (Schumpeter 1939). It also helps to compare and contrast him with Marx. Whereas Schumpeter started with the circular flow of economic life, Marx started with the circuit of social capital. Schumpeter's circular flow operates when there are workers and rentiers, but no capitalists or entrepreneurs. There is also no profit or surplus value. Oakley thinks this circular flow is a vacuous tool since it abstracts from core elements of the system.

Oakley also notes that whereas Marx started with accumulation and the capitalist-worker relationship, after the circular flow analysis Schumpeter started with innovation and the entrepreneur. Potential surplus value is generated from product, process, raw material, market and spatial-global innovation. Surplus value stimulates competition and thus upswing in the cycle, but competition reduces surplus value when the downswing generates lower prices and more commodities for workers. Oakley similarly thinks this is unrealistic, and prefers a system of heterogeneous innovations that are suitably analysed and modelled. More critically, Schumpeter is taken to task for failing to incorporate embodied technical change into the accumulation process. His emphasis on qualitative over quantitative has thus reduced the viability of his theory.

Schumpeter places major emphasis on competition in the business cycle, even though in his 1942 book on Capitalism, Socialism and Democracy (Schumpeter 1942), he introduces monopolistic competition into his analysis. Unfortunately, no attempt was made to link degrees of monopoly to business cycles; monopoly was rather linked to the theme of creative destruction rather than cyclical developments. Oakley agrees with Paul Sweezy (1943) that business cycle analysis needs to include variable degrees of monopoly power, in order to make it more realistic and relevant to more mature stages of capitalism. Being able to link it to Michal Kalecki's system might also have helped in this respect.

Schumpeter focused a good deal of his analysis of cycles on money and credit. This is best explored with reference to his method of successive approximations. Starting with the circular flow, there are no innovations, no credit and no cycles. Introducing innovation financed by credit, provided by capitalist bankers, enabled innovation to occur. This is the first approximation to the real world through the primary business cycle, according to Oakley. In this primary cycle there are no real crises or depressions, only so-called 'recoveries' and 'recessions'. Crises and depressions emerge in the second approximation to the real world, or the secondary cycle, through the introduction of unproductive debt, which finances general accumulation rather than innovation. Such debt exacerbates the amplitude of the cycle through unproductive investment and speculative bubbles, generating 'booms' and 'depressions'. Hence the creation of a four-phase cycle (recovery, boom, recession, depression) which, according to Schumpeter, approximates reality better than the first approximation or the primary cycle. 
Schumpeter's third approximation introduces multiple cycles, specifically the schema of Kitchin cycles (3-5 years), Juglar cycles (7-11 years) and Kondratieff cycles (56 years). Schumpeter recognised that multiple cycles link to innovations of varying periodicity and durability. This introduces a further increase in the amplitude of the cycle, since during simultaneous downswings in the three cycles there are deep depressions. It may be necessary to use the government to stabilise the system; thus Schumpeter realised some critical problems with free market capitalism. Although not strictly following from his theory, the three-cycle system was seen by Schumpeter as an attempt to be more realistic and historically specific.

Oakley was somewhat sympathetic to his inclusion of money and credit in the schema, and also to the necessary generation of instability, as integral to modern capitalism. But ultimately Schumpeter is again taken to task, this time for ignoring the traverse - the temporal pattern of changes that are manifested as growth and accumulation (Oakley 1998) — and for failing empirically to validate the swarming of innovations that is necessary for cycles. Such swarming is assumed to occur in bunches, with many innovations being developed in synchrony. Oakley concludes that the introduction of Kitchin, Juglar and Kondratieff cycles adds nothing to the theory, while the statistical and historical context provided by Schumpeter is unimpressive.

Overall, although Oakley supported Schumpeter's analysis of instability, he preferred the Marxian/Keynesian method of linking accumulation with innovation; replacing the circular flow with something like the circuit of social capital and/or extended reproduction schemas; putting the capitalist as accumulator and innovator more into the system, rather than assuming capitalists to be mere credit facilitators; and including workers and the spheres of production-circulation more into the process of instability. Oakley thus saw advantages of linking Schumpeter's key insights with classical Marxian and post-Keynesian themes.

Of the six book reviews of Oakley's Schumpeter book I found in the journals, four concluded it was first class, one thought it was fine, while one said it was poor. For instance, one of the fathers of neo-Schumpeterian economics, Arnold Heertje (1992), in the Journal of Evolutionary Economics, praised it continually for being 'impressive', 'critical', and 'consistent', concluding that Schumpeter scholars 'must' read Oakley's book. Charles Staley (1992) in History of Political Economy agrees, arguing that 'This is definitely a book that anyone interested in Schumpeter must study thoroughly'.

Hans E. Jensen (1991), in the Economic Journal, concluded that 'It was Oakley's objective to specify the kinds of doors that Schumpeter opened, to point out what is hidden behind them, and to explain how that which is hidden may provide a basis and impetus for further research. In these endeavours, Oakley succeeded brilliantly'. Paul Killebrew (2001), in the Southern Economic Journal, said 'This book represents a valuable addition to the literature on Schumpeter. In terms of fulfilling its objective, this book should clearly be judged a success'.

Richard Swedberg (1992), in the Journal of Economic Literature, is the odd man out when he stated that Oakley's work is 'pedantic', 'ungenerous to Schumpeter', and has 'not properly highlighted' Schumpeter's 'historicosociological-economic vision'. That this is a one-sided view of 'Oakley's Schumpeter' is highlighted by Chris Freeman's (1991) review. Freeman agrees with Swedberg on one point, that 'Perhaps Oakley would have found it easier to maintain "empathy" if he had taken somewhat greater account of the historical and personal background of the books and papers which he analyses and the 
sociological contributions which he chose not to include in his critique' (p. 499; but see Oakley 2005). Yet he concludes that 'this is a valuable book', especially since Oakley 'exposes some of the glaring inconsistencies in Schumpeter's theory, most notably the uneasy compromise between Walrasian static equilibrium theory and his insistence that the system never could be in equilibrium'. Furthermore, he adds, 'the most incisive critique is Oakley's analysis of monopoly and the rate of profit in capitalist economies’ (p. 499).

\section{Structure-Agency Nexus, Austrians and the Reconstruction}

Oakley's analysis of the political economy of Marx and Schumpeter led him to adopt a humanistic perspective to political economy. That is, he believed that human beings must be the starting point as well as the finishing point of the analysis. Marx recognised this as appropriate when he stated that human beings shape the world, but not necessarily in the way that they would like. Humans are therefore affected by institutions and relationships that may constrain as well as enable action. Examining this relationship between human agency and structure is the most difficult, yet also the most important area of economics. Oakley focused on this problem especially during the 1990s and 2000s.

Such work started with his investigations of Adam Smith and J. S. Mill in Classical Economic Man (Oakley 1994a; see also Oakley 1993) and continued through his three volumes on Austrian economics. The first of these was The Foundations of Austrian Economics from Menger to Mises: A Critico-Historical Retrospective of Subjectivism (Oakley 1997a, see also Oakley 1997b), the second was The Revival of Modern Austrian Economics: A Critical Assessment of its Subjectivist Origins (Oakley 1999a), while the third, Reconstructing Economic Theory: The Problem of Human Agency (Oakley 2002a), included but went beyond Austrian themes.

In these three books, Oakley critically analyses the Austrian research programme of linking subjective agency with market processes. He asks the question: do Austrian scholars provide an adequate subjective foundation to their understanding of markets and competition? Mostly he answers in the negative. Austrians tend to be realists, while often making unrealistic assumptions about human behaviour in the market. They are inclined to be humanists in their vision, while often reverting to a mechanical view of agents in the market. They tend often to link agency with structure, while usually underplaying the role of structure in enabling human beings to achieve their objectives. These contradictions perplexed Oakley and led him to study subjectivism in more detail, ultimately trying to solve the critical problem of agency and structure. Overall, Oakley believes that the Austrians failed adequately to incorporate the full corpus of subjectivism into their economics, especially in relation to rational human action. For instance, in his first book on the Austrians, von Mises is said to be a realist, while taking an a priori approach to human rationality, which is anti-realist (Oakley 1997a, pp. 238-9).

This led Oakley in his second book on the Austrians to explore whether the same problem exists for more modern scholars, including Friedrich Hayek and Ludwig Lachmann. According to them, individuality and subjectivism lead to a multitude of interpretations, methods and ways of individuals acting; including reflection, creativity, innovation, sublimation and overreaction. The world is fundamentally uncertain in the sense that we know nothing of the future, yet we are required to plan different courses of action for the life process to continue. 
Interpretation of data and situations, in particular, requires many resources and path-dependent adjustments to a complex environment. Individuals act in order to make sense of and survive in an environment of change and motion. The multifarious ways in which people do this raises the question of whether a reasonable degree of coordination is possible for the economy as a whole. Can order be generated from the millions of different actions and interpretations of individuals in an environment of uncertainty?

Oakley argues that Hayek and Lachmann were able to situate the main problems, but failed to develop the analysis sufficiently to solve the core issues of subjectivism versus order. Hayek's main solution was to recognise that different knowledge profiles could be satisfied by different degrees of market dissemination of knowledge to achieve order. Oakley disagrees, raising questions about how useful this knowledge is in non-equilibrium processes, and how order is possible in a world of uncertainty and continual change. Ultimately, Hayek also uses countless a priori statements that are counter to a proper realist interpretation of the world. Lachmann's analysis of expectations, disequilibrium and hermeneutics was insightful but 'gave only the barest indications of the desired direction' to take (Oakley 1999a, p. 177).

Thus, the early and modern Austrians failed to provide an adequate subjectivist interpretation of markets and uncertainty in a way that is consistently realistic and evolutionary. ${ }^{6}$ Oakley concludes that the only recourse is a reconstruction of subjectivism from new roots. Thus in his most recent book, Reconstructing Economic Theory (Oakley 2002a), he attempts to do just this, to provide an ontological alternative foundation for economic science through comprehending the agency-structure nature of reality. He uses the work of Alfred Schutz, Karl Popper, George Shackle, Herbert Simon and Anthony Giddens in undertaking this reconstruction process.

Oakley outlines Schutz's coherent analysis of the subjective and intersubjective dimensions of human agency, but criticises him for underplaying the role of time in posing limits to knowledge (see also Oakley 2000a). Popper is taken to task by Oakley for overplaying rationality and objectivism, while his method of situated human action is found to be potentially useful for the reconstruction process (see also Oakley 1999b). ${ }^{7}$ Oakley supports the role of imagination and expectations in the work of Shackle, and the cognitive limits of the human mind in Simon, but worries about the tinge of orthodoxy in Simon through the notion of acquiring knowledge to reduce uncertainty. Ultimately, though, Oakley finds the work of Anthony Giddens to be the key to the further reconstruction required, especially his notion of 'structuration'.

Giddens develops his agency-structure analysis through dual interdependency between individuals and society. Individuals exist, as also do structures, and the critical thing is to recognise the linkages between them. Structures include things such as institutions, families, corporations, states and associations. Individuals also exist independently of structures in specific timespaces. Structures provide routines and resources that condition as well as enable individuals to function and achieve their objectives. Individuals also contribute to structures, as they perform various tasks, often with quite peculiar and original associations, and often in tandem with others. Structuration, therefore, is a complex process whereby the nexus between individuals and the structures they confront contributes to the reproduction of their everyday lives. 
According to Giddens (1986), uncertainty is especially notable in the globalised and neoliberal forms of capitalism, so a critical element of historical specificity leads to varying degrees of change and instability through time. This uncertainty will impinge on individuals, with hermeneutic cross-causation impacting back on the structure. Individual rationality is heavily bounded as a result, since the future is, especially now, heavily conditioned by deregulated processes and relationships. Along with this uncertainty is a high degree of potential instability in intimate relationships, especially since traditional social organisation has given way to high-modernism where individual freedom is a critical objective of the political and social process, as it is also among many individuals. More than anyone else, Giddens seeks a decentred view of agencystructure with time-space interactions and micro-macro interlinkages. ${ }^{8}$

The seven journal reviews I found of Oakley's work on the Austrians and the required reconstruction were mostly full of praise. It is certainly true that one must see these three books as a whole, since they follow one another logically. Trying to view the first volume without even mentioning some of the further work to come, as Mark Blaug (1998) and Anthony Endres (1999) do, even when Oakley clearly announced the forthcoming publication of the second volume (Oakley 1997a, p. 240), leads one inappropriately to criticise it for not planning (or including) further work on the theme. Once the second book emerged (Oakley 1999a), reviewers were able to analyse it in the context of a wider study (more so once the third emerged).

Karen Vaughn (2001), for instance, did recognise the ongoing nature of Oakley's research, since 'subjectivist economics remains an incomplete project. This is a [view] with which I heartily agree, although I find the project significantly less incomplete than does Oakley'. She goes on to say that 'Oakley does an admirable job of laying out the subjectivist credentials of Mises, Hayek and Lachmann. However, even more important is how this book lays the groundwork for further debate'. She concludes that 'Sensible Austrians cannot argue with the ontology and epistemology Oakley presents as underlying a human science' (Vaughn 2001, p. 112).

Oakley's (2002a) latest book, the third in the trilogy, lays the analytical foundations for a reconstruction of political economy based on realism, subjectivism and historico-critical inquiry into the limits of human understanding in a world of uncertainty. The reviews were mostly supportive, although some expected him to provide all the answers and fully reconstruct the new science from the ground up. Paul Lewis (2004), in the Review of Austrian Economics, believes that Oakley's 'claim about the usefulness of drawing on social theory and philosophy in order to provide a basic conceptual framework for economic analysis is spot on'. Expecting him to provide all the answers, Lewis concludes that 'Oakley's book seems more like a promissory note or preliminary note than a fullyfledged contribution' (p. 454). Stephen Parsons (2003), in the History of Economics Review, wondered why Oakley concentrated on certain theorists while supporting Anthony Giddens' theory of situated agency, but otherwise eagerly awaited the next volume of Oakley's reconstruction.

Other reviewers realised the magnitude of the task, and were more satisfied with the direction Oakley provided for such a reconstruction. A very long review by Brian Loasby (2005) in the Journal of Economic Methodology fully supported the theoretical superstructure provided by Oakley, including the priority of ontology, the human predicament of uncertainty, the principle of critical realism, the duality of action and routines, and the constraints and enablers of institutions and organisations. 
Oakley has thus come full circle. Drawing on Marx and Schumpeter, he recognised the incessant process of creative destruction and dynamic motion led to a high degree of uncertainty and instability of the capitalist process. Wanting to deepen the role of agency vis-à-vis Marx, and structure à la Schumpeter, he drew on subjectivism as a way of solving the riddle of the individual-society problem. Recognising that the Austrian approach created contradictions between subjectivism and market order, he sought ways in which this problem could be solved. Finding, ultimately, that the solution required nothing less than a complete reconstruction of economic theory, he went beyond the Austrians, and finally settled on Giddens as pointing the way to the future of what is to be done. In this he realised the need for a social view of political economy, the co-reproduction of individuals and structures, and a 'Third Way' of using utopian-realism to comprehend the socio-historical roots of economic action.

\section{Conclusion}

Allen Oakley made major contributions to comprehending the unstable motion of capitalism. He commenced his career through a scrutiny of the evolution of Karl Marx's political economy, continued the 'dynamic motion' theme through the works of Joseph Schumpeter, followed by a long process of analysing agencystructure in the work of classical political economy and the Austrian School. Even his agency-structure work continued the earlier theme of instability, through the potential of subjectivists to scrutinise problems of market disorder.

Oakley found that Marx's political economy evolved through time, and that the three main volumes of Capital (Marx 1867, 1885, 1894) were possibly one part of a much larger research programme. It is likely that Marx still believed in the intellectual need for something like the six-book plan of capital, wage labour, landed property, the state, foreign trade and the world market and crises-or at least the four-book plan of capital, the state, foreign trade, and the world market and crises-at the time of writing Capital, even if he did not foresee himself providing such a 'completed' work. Some evidence for this is that nowhere did Marx detail much about wage-labour, landed property, and especially the state or the world market; his analysis of crises was fragmentary; and he often comments on material that would hopefully be examined 'later'. Scholars need to recognise this when analysing Capital, and also (more especially) when scrutinising the nature of the political economy of contemporary capitalism.

Oakley's material on Schumpeter was more critical than that on Marx. On the one hand, Oakley was sympathetic to the need for endogenising innovation and the entrepreneur; incorporating money and credit into the schema; and explaining the cyclical and wave-like patterns of capitalism. But he saw the need to modify Schumpeter's work through introducing capitalists at the inception of discourse, linking accumulation with innovation, incorporating different degrees of monopoly in the analysis, providing a heterogeneous view of innovation, and critically evaluating the swarming of innovation. But he was sympathetic to Schumpeter's realistic vision, albeit with the need for major revisions to adapt to real world phenomena.

At this point in his intellectual development Oakley centred more specifically on the relationship of agency with structure. He likely thought that Marx underplayed agency, and that Schumpeter underplayed structure. His exploration of classical political economy led him to see the need for analysing the dual interplay of agency with structure. He then undertook a massive project of 
seeking to rectify the contradictions of subjectivism by providing a humanistic perspective on market order and instability. Then followed two books on Austrian economics per se, and a third volume setting the foundations for solving the problem of subjectivism and order.

The main contradiction of the Austrian School is that it developed a subjectivist view of economic action while underplaying the role of uncertainty, cognitive problems and time in generating market instability. Subjectivism, according to Oakley, necessarily leads to problems of market disorder. This is because it incorporates motion, action and change; the very things that lead to disequilibrium, traverse and path dependence. Oakley concluded that, while some Austrians recognise the problem, they are unlikely to solve it within the framework of their status-quo perspective. Ultimately, he decided, it requires the work of a social scientist with a background of interdisciplinary analysis, socio-political processes and progressive politics. If we follow Oakley with this research programme, we are likely to contribute to comprehending socio-economic action, instability and traverse motion and evolution. Such is the task that Oakley set himself and others to follow for advancing the state of political economy into the future.

* Global Political Economy Research Unit (GPERU), Department of Economics, Curtin University, GPO Box U1987, Perth WA 6845, Australia. Email: philohara1@yahoo.com. I wish to thank the referees, Allen Oakley and Jerry Courvisanos, for comments on earlier versions of this paper.

\section{Notes}

1 Much of this biography section is dependent on Oakley (2006), although a considerable amount also relies on my own knowledge of Allen since 1980, when I first met him in Sydney. During 1978, when I wrote my honours thesis, his work on the evolution of Karl Marx's critical inquiry into political economy was crucial for my comprehension of Marx's analysis of crises and business cycles (O'Hara 1978). Geoffrey Harcourt, on reading my thesis, suggested that I get to know and work with Allen. So when I got my first academic job at the Kuring-Gai College of Advanced Education (later part of the University of Technology, Sydney), Allen visited my girlfriend and me from time to time. We often met when he was coming to Sydney, and I enrolled in a Masters under his supervision in 1982. Then I moved to Newcastle for three years to study for a $\mathrm{PhD}$ under his supervision. While in Newcastle I read most of his papers and books, and regularly discussed his work, often also with his wife, Renate, over a barbecue or lunch. We have continued communication ever since then. Allen also did some work refereeing articles for the Encyclopedia of Political Economy (O’Hara 2001).

2 Allen Oakley went on to write two articles on the contributions of Geoffrey Harcourt to political economy. In the first (Oakley 1996), he examined 'The Economic Wisdom of G. C. Harcourt', by reviewing a fifth volume of selected Harcourt articles (Harcourt 1995). He concludes the essay by stating that 'This is a fine collection of essays by a scholar who brings a rare warmth and personal insight into some very difficult corners of our subject. The reader here learns much about economics as a human science of the real world' (Oakley 1996, p. 287). In the second such article of Oakley, about two of the Harcourt Festschrift volumes, Oakley concludes that these 'volumes ... honour one of Australia's greatest scholars. ... [A]ll Australian economics students who are serious about their discipline deserve to be made aware of the 
outstanding contributions made by Geoff Harcourt to the heterodox facets of its development' (Oakley 2000b, p. 90).

3 Examples of those who assumed the completeness of Capital, and failed to raise the possibility of the need to go beyond it, or examine evolutionary modifications, within Marx’s framework, include Fred Gottheil (1966), Gerard Maarek (1975) and Meghnad Desai (1979). For instance, Maarek (1975, p. xviii) even goes as far as to argue that 'I will not study any changes in Marx's thinking on any particular subject during the long period when he was writing his work: Das Kapital will be considered as a whole, without any internal contradictions'.

4 It was left for non-political economists to investigate this question. Roman Rosdolsky (1968), for instance, undertook a general analysis of Marx’s plans while analysing the role of the Grundrisse in Marx's intellectual development. However, few political economists studied this work, and far fewer still examined its significance for various models of political economy. Michael Lebowitz (1982, 1992) has looked into various aspects of this plan and its implications for political economy, especially vis-àvis 'wage labour'; as has O’Hara (2000).

5 Oakley also recognised that there was some evidence Marx may have also considered seriously the need for a four-book plan, even if he was not going to complete it, including (1) Capital, (2) the State, (3) Foreign Trade, and (4) the World Market and Crises. In this case, the former books (2) Wage Labour, and (3) Landed Property were integrated into (1) Capital, at least to some significant degree. Another possibility is that Marx eventually saw 'Capital' as the major plan, with the others left out of the analysis as separate books. More likely, probably, is that Marx saw the need to concentrate on 'Capital' in his lifetime, but saw a further requirement for others to complete a fuller working of one of the extended plans, possibly the six-book plan (see Oakley 1983).

6 Reference should be given here to a critically realist vision provided by Adolf Lowe, who engaged in a dispute with Hayek on business cycle debates. Oakley's (1987) edited book, devoted to the republication of some of Lowe's papers, pays a lot of attention to questions of methodology. In a very long review of this book by Richard Chase (1989), Chase concludes that 'Oakley's Introduction is first rate. It provides the reader with clearly presented descriptive and analytical materials that serve well to orient him or her and to whet one's appetite for the exploration to come' (p. 109). Ed Nell (1989) described Oakley's introductory essay as 'compact and thoughtful', and for the book as a whole, 'Here is a fully-fledged attempt to work out a modern economics that is neither sterile nor ad hoc, based on a rethinking, in modern terms, of the viewpoint of the Classics and Marx. It is what many have been asking for' (see also Oakley 1994b).

7 Oakley went on to study Popper's analysis of method, rationality, situated human action and linkages with economics in a number of other works, such as Oakley (1999c, 2000c, 2002b). He generally had reservations about Popper's analysis of rationality, while being sympathetic, for instance, to his theory of situated human action.

8 Giddens is one of the leading sociologists of all time. Similar to the institutionalists, he takes a holistic approach, and like more modern political economists he tries to integrate structure and agency in his analysis. Politically, he takes a third way, like Tony Blair and Bill Clinton, but tends to redefine left and right from a progressive standpoint. Sociologically, he is holistic in trying to situate individuals in a social fabric that is continually in the process of becoming. Eschewing voluntarism and structuralism, he seeks to reconstruct social science within a more integrated framework. Unlike the Austrians, he does not have a blind faith in the market process, or free market approaches. In reconstructing subjectivism in the direction of Giddens's sociology, Oakley is taking a more progressive approach, while casting aside Austrian fundamentalism in the search for sociological roots of political economy. 


\section{References}

Blaug, Mark. 1998. 'Review of Allen Oakley, The Foundations of Austrian Economics from Menger to Mises: A Critico-Historical Retrospective of Subjectivism', Manchester School, 66(4), pp. 507-8.

Chase, Richard X. 1989. 'Unity in the Social Thought of Adolf Lowe: A Review of Essays in Political Economics: Public Control in a Democratic Society', American Journal of Economics and Sociology, 48(1), pp. 101-11.

Courvisanos, Jerry. 1994. A Kaleckian Behavioural Theory of Investment Cycles. $\mathrm{PhD}$ thesis. University of Newcastle. Supervisor: Professor Allen Oakley.

Courvisanos, Jerry. 1996. Investment Cycles in Capitalist Economies: A Kaleckian Behavioural Contribution. Cheltenham, UK \& Brookfield, US: Edward Elgar.

Desai, Meghnad. 1979. Marxian Economics. Oxford: Basil Blackwell.

Elliott, John. 1986. 'Review of Allen Oakley, Marx's Critique of Political Economy: Intellectual Sources and Evolution. Volume 1, 1844 to 1860; Volume 2, 1861 to 1863', American Political Science Review, 80(4), pp. 1329-32.

Elliott, John. 1987. 'Review of Allen Oakley, The Making of Marx's Critical Theory: A Bibliographical Analysis', History of Political Economy, 19(1), pp. 165-6.

Endres, Anthony M. 1999. 'Review of Allen Oakley, The Foundations of Austrian Economics from Menger to Mises: A Critico-Historical Retrospective of Subjectivism', Economic Journal, 109, pp. F271-F272.

Evans, Michael. 1985a. 'Review of Allen Oakley, Marx's Critique of Political Economy: Intellectual Sources and Evolution. Volume 1: 1844 to 1960', Manchester School, 52, pp. 113-15.

Evans, Michael. 1985b. 'Review of Allen Oakley, Marx's Critique of Political Economy: Intellectual Sources and Evolution. Volume 2: 1861 to 1863', Manchester School, 52, pp. 337-9.

Freeman, Chris. 1991. 'Review of Allen Oakley, Schumpeter's Theory of Capitalist Motion: A Critical Exposition and Reassessment', Journal of Evolutionary Economics, 12(1), pp. 83-4.

Giddens, Anthony. 1986. The Constitution of Society: Outline of the Theory of Structuration. Los Angeles: University of California Press.

Gottheil, Fred M. 1966. Marx's Economic Predictions. Evanston: Northwestern University Press.

Harcourt, Geoffrey C. 1995. Capitalism, Socialism and Post-Keynesianism: Selected Essays of G. C. Harcourt. Aldershot, UK: Edward Elgar.

Heertje, Arnold. 1992. 'Review of Allen Oakley, Schumpeter's Theory of Capitalist Motion: A Critical Exposition and Reassessment', Manchester School, 59, pp. 448-9.

Heilbroner, Robert L. 1953. The Worldly Philosophers: The Lives and Times of the Great Economic Thinkers. Fifth edition. New York: Simon \& Schuster, 1980.

Jensen, Hans E. 1991. 'Review of Allen Oakley, Schumpeter's Theory of Capitalist Motion: A Critical Exposition and Reassessment', Economic Journal, 101(408), pp. 1311-12. 
Killebrew, Paul. 2001. 'Review of Allen Oakley, Schumpeter's Theory of Capitalist Motion: A Critical Exposition and Reassessment', Southern Economic Journal, 58(3), pp. 840-1.

Lebowitz, Michael. 1982. 'The one-sidedness of Capital', Review of Radical Political Economics, 14(4), pp. 40-51.

Lebowitz, Michael. 1992. Beyond Capital: Marx's Political Economy of the Working Class. London: Macmillan, second edition, 2002.

Lewis, Paul A. 2004. 'Review of Allen Oakley, Reconstructing Economic Theory: The Problem of Human Agency', Review of Austrian Economics, 17(4), pp. 453-5.

Loasby, Brian J. 2005. 'Review of Allen Oakley, Reconstructing Economic Theory: The Problem of Human Agency', Journal of Economic Methodology, 12(4), pp. 606-13.

Maarek, Gerard. 1975. An Introduction to Karl Marx's Das Kapital: A Study in Formalisation. New York: Oxford University Press, 1979, translated by Mansel Evans, with a Foreword by W. J. Baumol.

Marx, Karl. 1857-58 [1973]. Grundrisse: Foundations of the Critique of Political Economy (Rough Draft). Harmondsworth: Penguin, translated with a Foreword by Martin Nicolaus. (First published in 1939 in German.)

Marx, Karl. 1859 [1970]. A Contribution to a Critique of Political Economy. Moscow: Progress.

Marx, Karl. 1861-63 [1988-89]. Economic Manuscript of 1861-1863. Moscow, Progress Publishers, (2 volumes). (Karl Marx and Frederick Engels, Collected Works, Volumes 30-31.)

Marx, Karl. 1862-63 [1963, 1968, 1971]. Theories of Surplus Value: Part I, II \& III. Moscow: Progress Publishers.

Marx, Karl. 1867 [1976]. Capital: A Critique of Political Economy: Volume 1-The Production Process of Capital. Harmondsworth: Penguin, introduced by Ernest Mandel and translated by Ben Fowkes.

Marx, Karl. 1885 [1978]. Capital: A Critique of Political Economy: Volume 2-The Circulation Process of Capital. Harmondsworth: Penguin, introduced by Ernest Mandel and translated by David Fernbach.

Marx, Karl. 1894 [1981]. Capital: A Critique of Political Economy: Volume 3-The Process of Capitalist Production as a Whole. Harmondsworth: Penguin, introduced by Ernest Mandel and translated by David Fernbach.

Mitchell, William F. 1999. Essays on Inflation and Unemployment. PhD thesis. University of Newcastle. Supervisor: Professor Allen Oakley.

Nell, Edward. 1989. 'Review of Allen Oakley (ed.), Essays in Political Economics: Public Control in a Democratic Society', Journal of Economic Literature, 27(2), pp. 603-4.

Oakley, Allen. 1972. The Theory of the Rate of Profits in English Economic Thought. Honours thesis. University of Adelaide. Supervisor: Professor Geoff Harcourt.

Oakley, Allen. 1976. 'Two notes on Marx and the transformation problem', Economica, 43(3), pp. 411-17.

Oakley, Allen. 1979. 'Aspects of Marx's Grundrisse as intellectual foundations for a major theme of Capital', History of Political Economy, 11(2), pp. 286-302. 
Oakley, Allen. 1980. The Evolution and Critico-Analytical Significance of Karl Marx's Theory of Surplus Value Prior to Capital. PhD thesis. University of Adelaide. Supervisor: Geoffrey C. Harcourt.

Oakley, Allen. 1983a. The Making of Marx's Critical Theory: A Bibliographical Analysis. London : Routledge and Kegan Paul.

Oakley, Allen. 1983b. 'What is Capital?', invited lecture on the occasion of the centenary of the birth of Karl Marx, Second History of Economic Thought Society of Australia Conference, University of Sydney. Published in History of Economics Review, 45, Winter, 2007.

Oakley, Allen. 1984. Marx's Critique of Political Economy: Intellectual Sources and Evolution. Volume 1, 1844 to 1860. London: Routledge and Kegan Paul. Reprinted 2003.

Oakley, Allen. 1985. Marx's Critique of Political Economy: Intellectual Sources and Evolution. Volume 2, 1861 to 1863. London: Routledge and Kegan Paul. Reprinted 2003.

Oakley, Allen (ed.). 1987. Essays in Political Economics: Public Control in a Democratic Society, by Adolph Lowe, edited with an Introduction by Allen Oakley, Brighton: Wheatsheaf.

Oakley, Allen. 1990. Schumpeter's Theory of Capitalist Motion: A Critical Exposition and Reassessment. Cheltenham: Edward Elgar.

Oakley, Allen. 1993. 'Human agency and methodology in classical political economy', History of Economics Review, 20, Summer, pp. 13-40.

Oakley, Allen. 1994a. Classical Economic Man: Human Agency and Methodology in the Political Economy of Adam Smith and J. S. Mill. Cheltenham: Edward Elgar.

Oakley, Allen. 1994b. 'Adolph Lowe', in G. Hodgson, W. J. Samuels and M. Tool (eds), Handbook of Evolutionary and Institutional Economics. Cheltenham: Edward Elgar.

Oakley, Allen. 1996. 'The Economic Wisdom of G. C. Harcourt', History of Economics Review, 25, pp. 284-8.

Oakley, Allen. 1997a. The Foundations of Austrian Economics from Menger to Mises: A Critico-Historical Retrospective of Subjectivism. Cheltenham: Edward Elgar.

Oakley, Allen. 1997b. 'Epistemological problems of human agency in Mises's subjectivism', History of Economics Review, 26, Winter-Summer, pp. 21-39.

Oakley, Allen. 1998. 'The traverse as a problem of human agency', in H. Hagemann and H. D. Kurz (eds), Political Economics in Retrospect: Essays in Memory of Adolph Lowe. Cheltenham: Edward Elgar.

Oakley, Allen. 1999a. The Revival of Modern Austrian Economics: A Critical Reassessment and Reconstruction of Subjectivism. Cheltenham: Edward Elgar.

Oakley, Allen. 1999b. 'Economics and the origin of Popper's situational analysis', History of Economics Review, 30, Summer, pp. 25-40.

Oakley, Allen. 1999c. 'Situational analysis and agent rationality: Shackle contra Popper', in C. Sardoni and P. Kriesler (eds), Keynes, Post-Keynesianism and Political Economy: Essays in Honour of Geoff Harcourt, Volume three. London: Routledge.

Oakley, Allen. 2000a. 'Alfred Schutz and economics as a human science', Human Studies, 23(4), pp. 243-60. 
Oakley, Allen. 2000b. 'Frontiers of Post-Keynesian and other heterodox economics: Essays in Honour of Geoff Harcourt', History of Economic Review, 31, Winter, pp. 79-90.

Oakley, Allen. 2000c. 'How rational is Popper's rationality principle? A reply to Boris Salazar', History of Economic Review, 30, Summer, pp. 63-6.

Oakley, Allen. 2002a. Reconstructing Economic Theory: The Problem of Human Agency. Cheltenham: Edward Elgar.

Oakley, Allen. 2002b. 'Popper's ontology of situated human action', Philosophy of the Social Sciences, 32(4), pp. 455-86.

Oakley, Allen. 2005. 'Joseph Alois Schumpeter', in The Oxford Encyclopedia of Economic History. New York: Oxford University Press.

Oakley, Allen. 2006. Biographical Notes about My Life and Ancestral Heritage. Medowie, New South Wales.

O’Hara, Phillip Anthony. 1978. A Critical Analysis of Marx's Analysis of Crises and Business Cycles. Murdoch University, Western Australia.

O'Hara, Phillip Anthony. 1992. A Critical Analysis of the Reproduction of Institutions Within Capitalism: Integrating Macroinstitutional Themes from Marxist and Institutionalist Political Economy. PhD dissertation. University of Newcastle. Supervisor: Professor Allen Oakley.

O’Hara, Phillip Anthony. 2000. Marx, Veblen and Contemporary Institutional Political Economy: Principles and Unstable Dynamics of Capitalism. Cheltenham, UK \& Northampton, US: Edward Elgar.

O'Hara, Phillip Anthony. 2001. Encyclopedia of Political Economy. London and NY: Routledge. Paper edition.

Parsons, Stephen. 2003. 'Review of Allen Oakley, Reconstructing Economic Theory: The Problem of Human Agency', History of Economics Review, 38, Summer, pp. 85-7.

Rosdolsky, Roman. 1968. The Making of Marx's 'Capital'. London: Pluto, 1977, translated by Pete Burgess.

Schumpeter, Joseph. 1911 [1967]. The Theory of Economic Development. Oxford: Oxford University Press.

Schumpeter, Joseph. 1939 [1982]. Business Cycles: A Theoretical, Historical, and Statistical Analysis of the Capitalist Process. Two volumes. Philadelphia: Porcupine.

Schumpeter, Joseph. 1942 [1975]. Capitalism, Socialism and Democracy. New York: Harper \& Row.

Staley, Charles E. 1992. 'Review of Allen Oakley, Schumpeter's Theory of Capitalist Motion: A Critical Exposition and Reassessment', History of Political Economy, 24(2), pp. 542-3.

Swedberg, Richard. 1992. 'Review of Allen Oakley, Schumpeter's Theory of Capitalist Motion: A Critical Exposition and Reassessment', Journal of Economic Literature, 30, pp. 181-2.

Sweezy, Paul. 1943. 'Schumpeter's theory of innovation', The Review of Economic Statistics, 25(1), pp. 93-6.

Vaughn, Karen. 2001. 'Review of Allen Oakley, The Revival of Austrian Economics: A Critical Assessment of its Subjectivist Origins', Economic Record, 77(236), pp. 110-12. 